\title{
Obituaries
}

\section{PATRICK ANTHONY EDWARD HUNT}

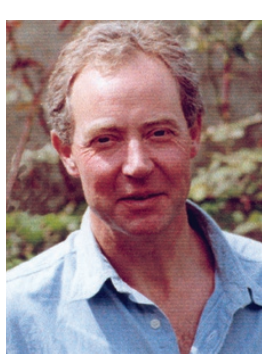

Patrick Hunt died peacefully on 6 January 2009 at Nazareth House, Plymouth, after an all too short battle with a malignant brain tumour.

Born at Crowborough, East Sussex in November 1940 and educated at Midhurst Grammar School, he attended The Royal Dental Hospital, qualifying in 1963. He joined the Boutwood Practice in Chichester, practising there until 1970. He then moved to Plymouth, joining Mann and Partners, soon becoming a partner. An excellent clinician with a lively enquiring mind, Patrick practised his dentistry to the highest standards. An inspiration to all around him, he also worked hard at the 'nuts and bolts' of running a busy threebranch dental practice and embracing new ideas such as computerisation. He took a keen interest in orthodontics.

Patrick spent many happy summers with his family in his wife Katarina's native Sweden, also practising there in Government clinics and drawing on his experiences in the different dental system. Patrick sat on the LDC for a number of years and in 1981 was Chairman of the BDA Plymouth section. In 1987 he left the Plymouth practice and moved to Torpoint in Cornwall where he practised privately from the elegant eighteenth century Tor House, a truly unique setting. He and Katarina were very active in the community, their annual fete becoming a firm fixture. Patrick was a keen sailor, a member of the Royal Western Yacht Club, and latterly of the Torpoint Mosquito Sailing Club, competing regularly in the Laser Class. Patrick retired from practice in 2005, sold Tor House and purchased a beautiful old maison in Aquitaine, typically throwing himself into its restoration, and into the life of the village community.

He was a linguist, fluent in French and Swedish.

A kind and thoughtful man who put people first, Patrick will be remembered with great respect and affection by his many friends, colleagues and patients.

He is survived by Katarina and their children Joanna and Charles.

Terence Higgins, Martyn Ellyatt

\section{DONALD HAYES NORMAN}

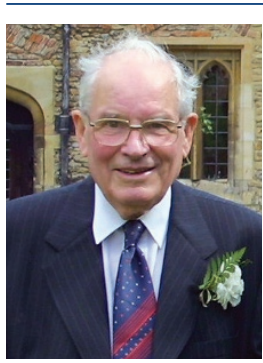

Donald Norman died on 26 February 2009, three months before his ninetieth birthday. He was born on 24 June 1919. During the war his father (Sir Charles Norman), director of Rank the millers, was in charge of animal feed rationing and planning for human food rationing if we were invaded, so Don was brought up for a lifetime of service. He entered Guy's Dental Hospital in 1937 and after gaining BDS and LDS he joined the RAF. In addition to dental duties he advised on clinical photographic facilities.

After leaving the RAF in 1946 he worked in general practice and then joined the school service, which became a lifetime passion. He worked for a variety of authorities, including the important Middlesex County Council. In 1954 he joined the borough of Hounslow, becoming its chief dental officer following the 1965 local government reorganisation, managing community clinics from his base in Bath Road. By retirement in 1983 he was area dental officer for Hounslow, Hammersmith and Ealing. He cared a great deal for his patients and staff. The latter received enormous support and a number subsequently made their marks on the profession. He often seemed quite stern, but usually there was a twinkle in his eyes.

From the beginning he supported the dental auxiliary (later therapist) scheme and was one of the first people to employ one. He was a part-time teacher of children's dentistry at the London Hospital. When plans were afoot for the major 1974 reorganisation of the NHS he was involved with the London and the King's Fund College in designing courses for dentists. To improve his knowledge he studied dental public health and gained the DDPH in 1973.

Photography was a passion. Many colleagues were taught about cameras and cajoled into buying equipment they didn't even know they needed. Through his encouragement health education in Hounslow was one of the best equipped departments in the country. He wrote a series on photography for Dental Update and articles for the BDJ, and used photographs to study tongue conditions associated with vitamin deficiencies, publishing results with Prof Yudkin in the Proceedings of the Nutrition Society.

Peggy, his wife of 60 years, predeceased him. He is survived by his son Arthur, daughter Heather, daughter-in-law Lucy, son-in-law David and grandchildren Richard, Natalie, Gabrielle and Oliver to whom we extend our deepest sympathy.

Brenda Fox , Stanley Gelbier 